\title{
Assessment of radiocaesium washoff transport from a pilot catchment in the first period after nuclear contamination
}

\author{
O. Slavik, M. Van der Perk' and J. Hofierka ${ }^{2}$ \\ VUJE Tmava a.s., Okruzna 5, 91864 Tmava, Slovakia \\ ${ }^{1}$ Utrecht Centre for Environment and Landscape Dynamics-UCEL, Faculty of Geographical \\ Sciences, Utrecht University, P.O. Box 80115, 3508 TC Utrecht, The Nethertands \\ ${ }^{2}$ GeoModel Ltd., Milana Marecka 3, 84107 Bratislava, Slovakia
}

\begin{abstract}
As part of the EC-funded project SPARTACUS a GIS-embedded radionuclide redistribution model was developed based on the existing LISEM soil erosion model. It simulates lateral radiocaesium transport and exchange in the active topsoil layer and runoff water in catchment during a rainstorm event. The model was applied for the assessment of the relative extent of radiocaesium transport from the Mochovce catchment following an accidental nuclear contamination using selected rainfall intensity scenarios. In this case, a $15 \mathrm{~mm}$ rainfall event during 30 minutes with a maximum rainfall intensity of $75 \mathrm{~mm} / \mathrm{h}$ during 8 minutes was selected to assess the effect of ploughing on ${ }^{137} \mathrm{Cs}$ transport. The model results demonstrate that particulate transport contributes considerably to the ${ }^{137} \mathrm{Cs}$ transport within and from the Mochovce catchment. The ${ }^{137} \mathrm{Cs}$ transport from unploughed soils appears to be a factor of 35 larger than the transport from ploughed soils. The implications of the model results for selecting appropriate mitigating measures to reduce ${ }^{137} \mathrm{Cs}$ following a nuclear accident are discussed.
\end{abstract}

\section{INTRODUCTION}

Radiocaesium $\left({ }^{137} \mathrm{Cs}\right)$ redistribution processes in a catchment are mainly related with the transport of fine soil particles and sediment, although the initial post-accidental transport of ${ }^{137} \mathrm{Cs}$ might have largely occurred in dissolved form [1]. Radiocaesium is very soluble in water, but also readily specifically adsorbed by illitic clay minerals [2]. As a consequence, ${ }^{137} \mathrm{Cs}$ become irreversibly fixed in mineral soils to clay minerals over the years. Modelling of these processes needs an advanced spatially distributed erosion and sedimentation model that has not been widely used for this purpose.

As part of the EC-funded project SPARTACUS a GIS-embedded radiocaesium redistribution model was developed. It simulates lateral radiocaesium transport during individual rainstorm events at the catchnent scale based on the existing LISEM soil erosion model [3] and a proposed ${ }^{137} \mathrm{Cs}$ interaction submodel.

The Mochovce catchment, Slovakia, was selected as one of the pilot catchments within the SPARTACUS project to adapt GIS based soil erosion models. Extensive hydrological and soil erosion related field observations including ${ }^{137} \mathrm{Cs}$ measurements in soil samples were conducted in the pilot catchment to test the soil erosion LISEM and the developed radiocaesium redistribution model. Soil samples were collected to determine radiocaesium exchange distribution parameters for the developed model.

Radionuclides deposited on the soil surface after a nuclear power plant accident could be a significant source of secondary contamination induced by a heavy rainstoms and subsequent wash-off processes. The extent of radionuclide wash-off transport depends on the character of the first rainstorm events and prevailing soil conditions with respect to fixation and remobilisation of radionuclides from the topsoil layer. Within the frame of the national part of the SPARTACUS project the main focus was devoted to use of the tested model for assessment of wash-off transport characteristics for the pilot catchment in relation with a hypothetical nuclear contamination. To conduct such assessment it is necessary to select appropriate rainfall intensity and soil erosion scenario that conservatively represent the expected worstcase situation. "Design" block rain intensity curves are available for about 70 Slovakian hydrometeorological stations [4]. They represent the maximum precipitation intensity period within a real rainfall event based on statistical frequency distributions and seem to be appropriate for the simulation of ${ }^{137} \mathrm{Cs}$ wash-off. The intensity curves are commonly used in the civil engineering for the design of for example run-off channel dimensions. 
The aim of this paper is to present the first modelling results of the assessment of the radiocaesium washoff transport from the Mochovce catchment following a potential accidental soil contamination by ${ }^{137} \mathrm{Cs}$ under various rainfall intensity and soil conditions in relation with.

The Mochovce catchment $\left(48^{\circ} 16^{\prime} \mathrm{N} 18^{\circ} 26^{\prime} \mathrm{E}\right)\left(3.7 \mathrm{~km}^{2}\right)$ is situated near the Mochovce NPP in the loesscovered hilly part of the Danube Lowlands in Western Slovakia. An artificial channel drains the upper part of the catchment. In the central part of the catchment a natural spring zone feeds a small stream flowing through a marshland in the broad valley bottom before it reaches the catchment outlet. The main land use is dense termophilous oak forest $\left(2.1 \mathrm{~km}^{2}\right)$ similar to the potential vegetation of this area. The central part of the catchment is used as arable land $\left(1.4 \mathrm{~km}^{2}\right)$ where the large scale land management with high level of mechanisation and fertiliser application dominates. Because runoff and erosion do not occur in the forested part of the catchment, the study has focused only on the arable part. Haplic Luvisols with a clayey loamy texture are the main soil type on the hillslopes under agricultural use. Winter wheat, rape, maize and spring barley dominate the crop rotation. The Chernobyl related ${ }^{137} \mathrm{Cs}$ deposition and total post-Chernobyl deposits amount to about 10 and $13 \mathrm{kBq} \mathrm{m}^{-2}$ respectively.

\section{THE RADIOCAESIUM REDISTRIBUTION MODEL}

\subsection{General model structure}

The event-based ${ }^{137} \mathrm{Cs}$ redistribution model has been based on the existing LISEM soil erosion model, which has been successfully adopted for catchments under various soil and climatic conditions [3]. This model accounts for interception, infiltration, surface runoff, splash and flow detachment, suspended sediment transport and deposition during individual rainfall events. The LISEM model was implemented in the spatio-dynamic modelling language of the PCRaster GIS [5] and was slightly simplified to reduce computation time and to improve numerical stability. The model calculates only one average water level per grid cell and it does not differentiate between overland flow and channel flow within a grid cell.

The soil erosion model has been extended by a radiocaesium exchange module, which simulates ${ }^{137} \mathrm{Cs}$ exchange amongst the adsorbed phase in the topsoil layer and suspended sediment and the dissolved phase in the runoff water. The module allows simulating particulate and dissolved ${ }^{137} \mathrm{Cs}$ wash-off due to single rainfall events. However, the transport of hot particles is disregarded in the model.

Radiocaesium exchange is calculated by means of two Kd steady state distribution coefficients. The first, $\mathrm{Kdb}$, describes ${ }^{137} \mathrm{Cs}$ mass exchange through the surface between the topsoil and runoff water, while the second, $\mathrm{Kds}$, between the suspended sediments the runoff water. It is assumed that equilibrium between the adsorbed and dissolved phases is reached instantaneously. The Kd values are estimated as function of sediment type and are assumed to be constant during the runoff event. The main reason for using a steady state interaction submodel was that it fits appropriately the simplicity of the calculation scheme of the LISEM model.

The models require a ${ }^{137} \mathrm{Cs}$ soil deposition map $\left(\mathrm{Bq} / \mathrm{m}^{2}\right)$ as an input. The ${ }^{137} \mathrm{Cs}$ activity concentration in the topsoil is estimated using soil bulk density and either an exponential depth distribution with an effective empirical median depth before the first ploughing or a uniform depth distribution over the plough layer after the first ploughing. The exponential depth distribution is simulated using a median depth for ${ }^{137} \mathrm{Cs}$, which depends on the time since initial ${ }^{137} \mathrm{Cs}$ deposition $\left(M=M_{0}\{)\right.$ and amounts to about $M_{0}=0.008 \mathrm{~m} /\left(\mathrm{year}^{3 / 2}\right)$ for neutral and loamy or loamy clayey soils [6]. For ploughed soil, it is assumed that a constant part of the ${ }^{137} \mathrm{Cs}$ is distributed uniformly over the plough depth.

For each time step, the dissolved ${ }^{137} \mathrm{Cs}$ activity concentration in the runoff water is calculated from the ${ }^{137} \mathrm{Cs}$ activity concentration in the active layer of the top soil, the ${ }^{137} \mathrm{Cs}$ activity concentrations in sediment eroded from the top soil layer, and the suspended sediment concentration in runoff water:

$$
C_{w}=\frac{C_{b s}}{K d_{b}} \frac{1+S S K d_{b}}{1+S S K d_{s}}, \quad C_{b s}=\frac{C_{\text {top }}}{1+1 / d l_{M} K d_{b}}
$$


Where, $C_{w}$ is ${ }^{137} \mathrm{Cs}$ concentration in runoff water $\left(\mathrm{Bq} / \mathrm{m}^{3}\right)$, SS suspended sediment concentration $\left(\mathrm{kg} / \mathrm{m}^{3}\right)$, $K d_{h}$ distribution coefficient $K d$ for soil-runoff water interaction $\left(\mathrm{m}^{3} / \mathrm{kg}\right), K d_{s}$ distribution coefficient $K d$ for suspended sediment-runoff water interaction $\left(\mathrm{m}^{3} / \mathrm{kg}\right), C_{b s}{ }^{137} \mathrm{Cs}$ activity concentration in active top soil layer after interaction with the runoff water, $(\mathrm{Bq} / \mathrm{kg}), C_{i o p}{ }^{137} \mathrm{Cs}$ activity concentration in active top soil layer before interaction, $(\mathrm{Bk} / \mathrm{kg}), d I_{M}$ mass thickness of the active top soil layer, i.e. soil bulk density times the thickness of the active top soil layer $\left(\mathrm{kg} / \mathrm{m}^{2}\right)$. The particulate ${ }^{137} \mathrm{Cs}$ activity concentration in runoff water is calculated using $K d_{s}$. Subsequently, the dissolved and particulate ${ }^{137} \mathrm{Cs}$ is mixed with ${ }^{137} \mathrm{Cs}$ from upstream grid cells. Furthermore, the ${ }^{137} \mathrm{Cs}$ activity concentration in the active top soil layer and the ${ }^{137} \mathrm{Cs}$ surface activity are updated each time step after the calculation of the deposited amount of sediment and interaction with the runoff rain water.

The main model output consists of water discharge and concentrations and fluxes of suspended sediment and ${ }^{137} \mathrm{Cs}$ (soluble and particulate form). They are represented as maps for user-defined time steps as well as time series at the catchment outlet.

\subsection{Model testing}

To test the event-based ${ }^{137} \mathrm{Cs}$ redistribution for the Mochovce catchment, the radiocaesium redistribution model was adopted for the rainfall event on 10-11 July 1999. The total rainfall during this rainfall event amounted to $6.4 \mathrm{~mm}$, but the soil was very wet due to various rainfall events in the preceding week. For the model simulations, a basic GIS database containing a digital elevation model, soil and land use maps at an original scale of 1:10000 was built on the basis of respective topographic maps, aerial photographs and field survey. The spatial distribution of ${ }^{137} \mathrm{Cs}$ deposition was obtained from geostatistical interpolation of $180{ }^{137} \mathrm{Cs}$ measurements in soil samples (see [7]). The basic maps were converted to PCRaster for further analysis and calculation. For modelling water discharge, the initial values for soil and land use related model parameters (amongst others vegetation height, leaf area index, Manning's n, random surface roughness, and saturated hydraulic conductivity) were obtained from field observations by Den Besten and Wielinga [8] in June 1999. The Manning's n, saturated hydraulic conductivity, and initial soil moisture content were calibrated visually by means of comparing observed and simulated discharge at the catchment. This rainfall event was simulated using a time step of $7.5 \mathrm{~s}$. Figure 1 shows the simulated and observed discharge. The observed discharge shows two peaks, of which the first peak is overestimated and the second peak is slightly underestimated. The time to peak discharge is underestimated by 30 minutes for the first peak and 63 minutes for the second peak. The simulated total discharge of $5.51 \times 10^{3} \mathrm{~m}^{3}$ corresponds reasonably well with the observed value of $5.53 \times 10^{3} \mathrm{~m}^{3}$.
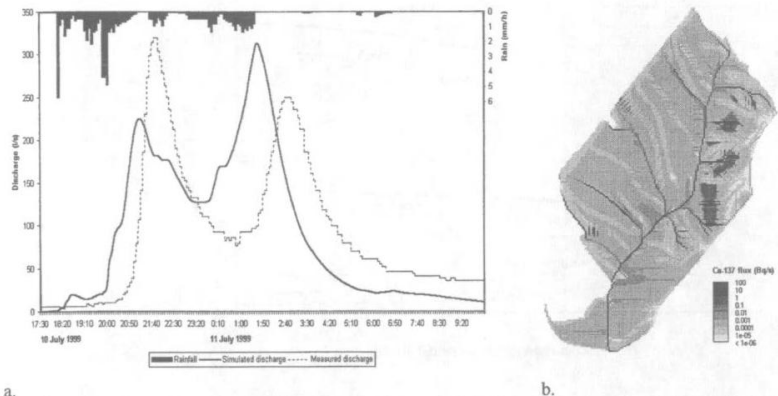

a.

Figure 1: Model results for the 10-11 July rainfall event: a) Calibration results: Measured and simulated water discharge, (b) Simulated spatial distribution of the total ${ }^{137} \mathrm{Cs}$ flux in the Mochovce catchments during peak discharge. 
From the model calculations, it appeared that the sediment and ${ }^{137}$ Cs transported through the main channel in the catchment was largely fed from a limited number of side-valleys (see figure $1 \mathrm{~b}$ ). Accordingly, the sediment concentration and the particulate ${ }^{137} \mathrm{Cs}$ activity concentration at the catchment outlet are largely determined by the amount of sediment that is transferred from the valley bottoms to the river channel. This is the main reason why it was not possible to identify the sediment and ${ }^{137} \mathrm{Cs}$ related model parameters at the hillslopes from the observed sediment concentrations at the catchment outlet. Therefore, we used the model parameter values for soil cohesion and grain size distribution of the soil as measured by Den Besten and Wielinga [8] and literature values for aggregate stability for the soil erosion submodel. The simulated erosion and deposition rates in the Mochovce catchment correspond well to values for similar soil and rainfall conditions reported in the literature (e.g. [9]).

The $\mathrm{Kd}$ values as input for the radiocaesium submodel were derived from laboratory experiments on samples from soils similar to soils in the Mochovce catchment. If the effects of irreversible ${ }^{37} \mathrm{Cs}$ fixation in soil are taken into account these values were determined at $K d_{b}=13.2 \mathrm{~m}^{3} \mathrm{~kg}^{-1}$ and $K d_{s}=39.7 \mathrm{~m}^{3} \mathrm{~kg}^{-1}$. The predicted pattern of total ${ }^{137} \mathrm{Cs}$ transport during peak discharge (figure $1 \mathrm{~b}$ ) obviously shows an enhanced transport from the steep slopes in the eastern part of the catchment. A large part of these transported ${ }^{137} \mathrm{Cs}$ is deposited on the valley bottoms. This pattern agrees well with the observed spatial distribution of ${ }^{137} \mathrm{Cs}$ in the Mochovce catchment (see [7]).

\section{RADIOCAESIUM TRANSPORT FROM THE MOCHOVCE CATCHMENT FOR DIFFERENT RAINFALL INTENSITY AND SOIL CONDITIONS}

\subsection{Rainfall intensity scenarios}

Using a block rainfall intensity curve as shown in figure 2, the 30 minutes long rainstorm event (30 $\mathrm{mm} / \mathrm{h}$ ) with a recurrence time of 1 year was selected as a basis for construction of the rainfall scenarios. On the basis of the rainfall intensity statistics shown in figure 2, the rainfall evolution was reconstructed for different 30 minutes rainfall events with respective $2,4,6,8,10,16$, and 20 minutes long periods of constant maximum rainfall intensity. These maximum rainfall intensities occur in the centre of the 30 minutes interval and amount to $136,105,88,75,66,41 \mathrm{~mm} / \mathrm{h}$, respectively. The constant rainfall intensities before and after the period of maximum rainfall intensity period were calculated from total amount of the 30 minutes long block rain $(15 \mathrm{~mm})$. In addition, a block rainfall scenario for a constant rainfall intensity of $30 \mathrm{~mm} / \mathrm{h}$ for 30 minutes was selected.

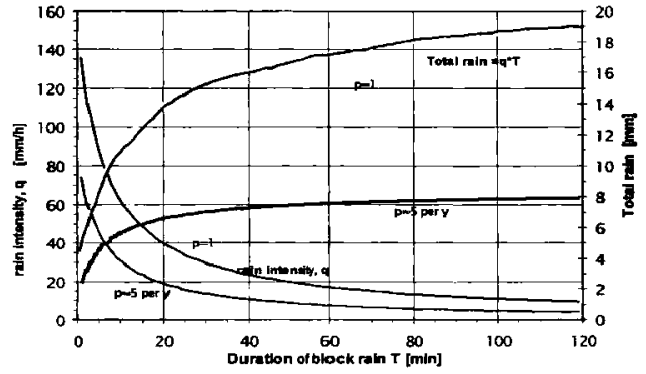

Figure 2: Block rain intensity and integral curve of given frequency, p, according to Urcikan \& Imrisek [4] as applied for the Mochovce catchment 


\subsection{Other model input}

For the scenario analyses, the model input with respect to hydrological and soil erosion parameters was taken from the model test run for the 10-1 1 July 1999 rainfall event as described above. This implies that the scenarios represent agricultural conditions in the first half of July about two weeks before harvest of the simulated winter wheat vegetation under very wet initial soil moisture conditions.

Because the scenarios represent conditions following deposition of ${ }^{137} \mathrm{Cs}$ following a nuclear accident, the soil contamination by ${ }^{137} \mathrm{Cs}$ of $10 \mathrm{kBq} / \mathrm{m}^{2}$ was assumed to be uniformly distributed over the entire catchment. Based on the above mentioned laboratory experiments the distribution coefficients for ${ }^{137} \mathrm{Cs}$ exchange were set to $K d_{h}=1 \mathrm{~m}^{3} \mathrm{~kg}^{-1}$ and $K d s=3 \mathrm{~m}^{3} \mathrm{~kg}^{-1}$. The soil was assumed to be unploughed with a active top soil layer of $5 \mathrm{~mm}$ thickness. To evaluate the effect of dilution of ${ }^{137} \mathrm{Cs}$ over the plough layer $(25 \mathrm{~cm})$ on ${ }^{137} \mathrm{Cs}$ wash-off, the model was also run for rainfall scenario that results in the maximum ${ }^{137} \mathrm{Cs}$ transport assuming a ploughed soil.

\subsection{Model results}

Table 1 summarises the model results for the most characteristic rainfall and ploughing scenarios. The results demonstrate that the rainfall evolution during a rainfall event with the same amount of rainfall within half an hour affects the total amount of transported sediment and ${ }^{137} \mathrm{Cs}$. The maximum relative loss of sediment and ${ }^{137} \mathrm{Cs}$ occurs for the BI-8mSh scenario during which $50 \%$ of ${ }^{137} \mathrm{Cs}$ is discharged in particulate form. If the rainfall is more evenly distributed over the 30 minutes period as it is in the case of the BI-4mSh scenario and the BI-30mSh scenario in particular, the rainfall becomes less erosive, which results in less loss of sediment and sediment-associated ${ }^{137} \mathrm{Cs}$. Accordingly, the relative importance of dissolved ${ }^{137} \mathrm{Cs}$ transport increases. Ploughing of the soil results in a considerable decrease in ${ }^{137} \mathrm{Cs}$ loss from the catchment by a factor of about 35 , but the relative importance of particulate ${ }^{137} \mathrm{Cs}$ transport increases.

Table 1: Predicted water, sediment, and ${ }^{137} \mathrm{Cs}$ discharges from the Mochovce catchment for different rainfall scenarios assuming $\mathrm{dl}=5 \mathrm{~mm}, \mathrm{~K}_{\mathrm{ds}}=3 \mathrm{~m}^{3} / \mathrm{kg}, \mathrm{Kdb}=1 \mathrm{~m}^{3} / \mathrm{kg}$, BI-xmSh block rain with $\mathrm{x}$ minutes long periods of constant maximum rainfall intensity.

\begin{tabular}{lllll}
\hline Rainfall scenario & BI-4mSh & BI-8mSh & BI-30mSh & BI-8mSh \\
& Unploughed & Unploughed & Unploughed & Ploughed \\
\hline Total runoff discharge $\left(\mathrm{m}^{3}\right)$ & $5210(23 \%)$ & $7070(31 \%)$ & $6230(28 \%)$ & $7070(31 \%)$ \\
Total sediment loss (tonnes) & 1.45 & 2.41 & 0.65 & 2.41 \\
Total ${ }^{137}$ Cs loss * (\%) & 0.085 & 0.035 & 0.021 & 0.0010 \\
Percentage ${ }^{137}$ Cs transport in particulate form (\%) & 46 & 50 & 26 & 65 \\
\hline
\end{tabular}

* Percentage of the total ${ }^{137} \mathrm{Cs}$ inventory in the agricultural part of the Mochovce catchment.

\section{DISCUSSION AND CONCLUSIONS}

The radiocaesium redistribution model was tested and applied for assessment of radiocaesium wash-off from the Mochovce catchment following an accidental contamination by ${ }^{137} \mathrm{Cs}$ for various scenarios of rainfall intensity and soil conditions with respect to ploughing. The model testing shows that it is particularly difficult to calibrate the sediment and ${ }^{137} \mathrm{Cs}$ transport at the catchment outlet, because the amount of transported sediment and ${ }^{137} \mathrm{Cs}$ is very sensitive to the amount that is transferred from the valley bottom. Therefore, we used values of model parameter related to sediment and ${ }^{137} \mathrm{Cs}$ transport from field measurements and the literature. Because the model could not be calibrated for sediment and ${ }^{137} \mathrm{Cs}$ transport, the model results are only indicative and should not be interpreted as absolute values. Nevertheless, the model results provide an opportunity to mutually compare the model results for the various scenarios. The model results presented here proved to be valuable for the assessment of the spatial 
relations determining post accidental secondary contamination. Also, the block rainfall intensity approach for the construction of rainfall scenarios proved to be useful for such an assessment. The method is simple and the required rainfall intensity curves are available from the literature.

It can be concluded that particulate transport contributes considerably to the ${ }^{137} \mathrm{Cs}$ transport within and from the Mochovce catchment. The maximum rainfall intensity and duration govern the total amount of sediment and ${ }^{137} \mathrm{Cs}$ loss from the catchment. For a $15 \mathrm{~mm}$ rainfall event of 30 minutes, the maximum sediment and ${ }^{137} \mathrm{Cs}$ losses occur in case this rainfall event contains a 8 minutes period of maximum rainfall intensity of $75 \mathrm{~mm} / \mathrm{h}$. Comparison of scenarios of unploughed and ploughed soils for this rainfall event shows that ${ }^{137} \mathrm{Cs}$ transport can be reduced by a factor of 35 if the soil is ploughed. This causes a uniform distribution of the ${ }^{137} \mathrm{Cs}$ previously contained in the top soil layer over the plough layer and, thus, a substantial reduction of the ${ }^{137} \mathrm{Cs}$ activity concentrations in the eroded top soil layer. This implies that high intensity rainfall events that occur before the first ploughing after ${ }^{137} \mathrm{Cs}$ deposition may result in a considerable ${ }^{137} \mathrm{Cs}$ redistribution within and export from the catchment.

Because sediment crosion and deposition governs the transport of ${ }^{137} \mathrm{Cs}$ to a great extent, ${ }^{137} \mathrm{Cs}$ transport following a nuclear accident can be reduced by measures that lead to 1 ) reduced ${ }^{137} \mathrm{Cs}$ activity concentrations in the top soil (e.g. ploughing), 2) reduced surface runoff (e.g. grass strips, improving the soil infiltration capacity or surface storage by ploughing), and/or 3) reduced sediment concentrations in the runoff water (retention sedimentation areas or ponds, soil conservation measures). Ploughing before the first rainstorm, i.e. practically immediately after radionuclide deposition, seems to be a good mitigating measure after a nuclear accident. The problem, however, is that such measure requires active participation of a human worker (tractor driver). Therefore, this measure may not be feasible in case of adverse radiological conditions due to individual radiation protection requirements. It is therefore also important is to consider long-term preventive measures that minimise the prevailing soil erosion processes in the catchment, for instance the conversion of arable land into grassland, or that ensure an effective retention of contaminated sediment in retention ponds in the most critical catchments.

\section{Acknowledgements}

This study was partly funded by the SPARTACUS project (EC Contract No. IC15-CT98-0215). The authors thank J.W. den Besten and A. Wielinga (Utrecht University) for collecting the soil samples, Dr E. Fulajtár (Soil Fertility Research Institute, Bratislava) and M. Hornak (VúJE Tmava a.s.) for their assistance during sample preparation and analysis, and Dr M. Suri, and T. Cebecauer (GeoModel Ltd.) for preparing the basic GIS database.

\section{References}

[1] J. Hilton, F.R. Livens, P. Spezzano, and D.R.P. Leonard, Sci. Tot. Environ. 129 (1993) 253-266.

[2] A. Cremers, A. Elsen, and P. De Preter, Nature 335 (1988) 247-249.

[3] V.G. Jetten, "LISEM - Limburg Soil Erosion Model", http://www.geog.uu.nl/lisem/

[4] P. Urcikan, L. Imriska, "Sewers and cleaning of waste water - tables for calculation of canals", (ALFA-SNTL, Bratislava-Praha, 1986) (in Slovakian)

[5] C.G. Wesseling, D. Karssenberg, W.P.A. van Deursen, and P.A. Burrough, Trans. GIS 1 (1996) 40-48.

[6] Slávik O., "Exploration of semiconductor gammaspectrometry for radiation control of nuclear power plant surroundings", (PhD thesis, Comenius University, Bratislava, Slovakia, 1990).

[7] M. van der Perk, O. Slávik, and A.A. Svetlitchnyi, "Redistribution of Chemobyl-derived radiocaesium across the landscape: field observations and spatial modelling", this volume.

[8] J.W.den Besten, and A. Wielinga, "Cs-redistribution in the Mochovce catchment, Slovakia, using a soil erosion and sedimentation model", (MSc thesis, Utrecht University, the Netherlands, 2000).

[9] A.P.J. de Roo, R.J.E. Offermans, and N.H.D.T. Cremers, Hydrol. Proc. 10 (1996) 1119-1126 